\title{
Geothermal Technology Application: A Case Study of Hot Dry Rock Technology in the Black Sea Basin
}

\section{Daria Nikiforova}

PhD student, NRU "Moscow Power Engineering Institute", Krasnokazarmennaya street 14, Moscow, Russian Federation

Email: KhitrovaDV@mpei.ru

Evgeny Lisin

Associate Professor of Economics, NRU "Moscow Power Engineering Institute", Krasnokazarmennaya street 14, Moscow, Russian Federation Email: lisinym@mpei.ru

\section{Wadim Strielkowski}

Assistant Professor, Faculty of social sciences, Charles University in Prague, Smetanovo nabr. 6, 11001 Praha 1, Prague, Czech Republic Email: strielkowski@fsv.cuni.cz

\section{Natalya Odintsova}

Undergraduate student, Department of Marketing Communication and PR, Faculty of social sciences, Charles University in Prague, Smetanovo nabr. 6, 11001 Praha 1, Prague, Czech Republic Email: onadi@bk.ru

\section{Doi:10.5901/mjss.2014.v5n21p425}

\section{Abstract}

This paper is focused on the geothermal technology application that is centered on the case study of hot dry rock geothermal technology in the Black sea basin. The paper tackles the innovative potential of the hot dry rock geothermal technology, in particular, the application of integrated assessment methodology based on the region's resources estimates, their structure and key performance indicators exemplified by the Krasnodar Region of the Black Sea area in the Russian Federation. Our results might be of a special interest for both political scientists, economists and international relations specialists, as well as for the local policy-makers and relevant stakeholders.

Keywords: technology applications, geothermal energy, hot dry rock technology, Black Sea region

\section{Introduction}

In spite of the developed network of centralized energy supply and the high level of electrification, there are decentralized energy supply systems on a large part of the territory of the Russian Federation. This is associated with low population density and a weak economic activity in areas which are remote from cities. For the decentralized energy supply systems are quite common case of "harp" power failure, which is caused by, in the first instance, unreliable energy resources supplies. This indicates the low energy security of a region. Moreover, in order to ensure energy for the population of remote areas diesel power plants are used the most often. This has a very negative impact on the environment (Ahmad et al., 2011; or Odeku, 2013).

The most promising solution to ensure energy security of regions and to comply with ecological compatibility requirements is a development and commissioning of innovative technologies in the field of energy generation, based on renewable sources of energy (RES).

Russian Federation is fertile in renewable energy sources. Almost every subject of the Russian Federation has 2 or 3 types of resources which are suitable to use. This fact opens courses of development for energy of the future. The priority development of RES has become a significant element of public technical policy in the field of energy in many 
countries. Production and accumulation of renewable energy will become the most rapidly growing segment of energy market in the next 20 years (see e.g. Smith Stegen, 2011). According to projections, the world turnover of this market will amount to 198.1 billion dollars by 2015 (see e.g. Yeqing and Hua, 2013; or Kirsten, 2014).

\section{Renewable Energy and Technology}

Despite the existence of legislative support, the share of renewable energy sources for electricity production less than 1 $\%$ in Russia at present, that is substantially lower than figures of industrial countries. If electricity production is considered as an economic system, then one of the reasons for the current situation is a weak understanding of the RES innovative potential magnitude and the lack of resources coordination for its implementation (Bilgin, 2011).

It is well known that in any economic system development of innovative potential plays a significant role. Innovative potential is a factor, providing an economic system growth due to innovations. In this case, innovations constitute a system of activities in research, development, exploitation, and depletion of productive-economic and socioorganizational potential underlying innovations, which serves as the innovation basis (see e.g. Turcan et al., 2013).

The innovative potential is defined by the complex of material, technical, personnel, financial and other types of resources, which can be used for the implementation of innovative activities. Besides, the innovative potential is a characteristic degree of region readiness to introduce innovations and includes a set of opportunities for the region to implement the innovation activity.

The structure of the innovative potential includes three components: a resource one, a functional and an efficient one. The resource component of the innovative potential describes promising possibilities of using specific types of resources in accordance with forecast expectations. The functional components include informational, infrastructural, managerial, and organizational constituents, which determine the ability of the system to attract resources for the creation and dissemination of innovations. Furthermore, it is responsible for the production of innovative product and the resumption of the innovation process cycle. The efficient component reflects the net result of the implementation existing means (in the form of a new product, obtained from the realization of the innovation process). It is also the target feature of the innovative potential. The close relationships between resource, functional and effective components of innovation potential determine the need to identify their optimum relationship (see e.g. Isaksson et al., 2010).

Furthermore, the question about evaluation of the innovation potential for geothermal technology in the Krasnodar region is considered in the article. The geothermal technology refers to renewable sources of energy and represents developing of energy contained in hot rocks, high temperature of which is supported by depth conductive thermal flow.

At present, construction of geothermal binary cycle plants is in progress, that is low-boiling working body in a circuit with a turbine is used for electricity generation. This way of a heat extraction from the Earth has a number of shortcomings: contamination of the heat-carrier, the need for an underground explosion and the high cost of the drilling and provision of the necessary facilities for more the one drillholes. Hot dry rock geothermal technology is deprived of given drawbacks. However, in comparison with geothermal power stations (GeoTPS) it has a lower surface of heat exchange, and, consequently, less installed potential. Additionally, the construction of petrothermal power station (PetroTPS) may be in any terrain regardless of groundwater availability.

Realization of the innovative potential of hot dry rock geothermal technology makes it possible to solve the following tasks:

- to enhance the reliability of autonomous power systems;

- to reduce harmful emissions into the environment from fuel and energy complex;

- to accelerate economic growth in sectors of the economy related to the RES;

- to ensure the availability of heat and electricity for people from remote areas;

- to release fuel energy resources.

The considered hot dry rock geothermal technology implies the construction of PetroTPS with installed capacity of $1000 \mathrm{KW}$ at the territory of the Krasnodar region, which would be supported in both the private and public order. PetroTPS has a year-round operation mode and stops only for regular overhauls, for this period it is expected to use the available diesel station.

\section{Classification of Methods for Evaluating Innovative Potential}

In the modern economic literature, there is no unified approach to assessment of the innovative potential (Tchereni, 2013). In less detail all considered methods for assessing potential can be systematized in groups in accordance with the 
three approaches: a resource one, a structural and an efficient one.

Table 1 summarizes a systematization of considered methods for evaluating innovative potential is given with indication of the fundamental framework for the assessment.

Table 1: Systematization of methods for assessing innovative potential

\begin{tabular}{|l|l|l|l|}
\hline & Resource-based approach & Structural approach & Efficient approach \\
\hline \multirow{5}{*}{ Criterion } & The level of financial sustainability & $\begin{array}{l}\text { The analysis of constituents: a resource one, an } \\
\text { internal and an efficient one. }\end{array}$ & $\begin{array}{l}\text { Indicators of efficiency of } \\
\text { resources use }\end{array}$ \\
\cline { 2 - 4 } & $\begin{array}{l}\text { Sufficiency of financial and } \\
\text { economic resources }\end{array}$ & The analysis of structure of the funding sources & $\begin{array}{l}\text { An input of balanced } \\
\text { performance indicators }\end{array}$ \\
\cline { 2 - 4 } & $\begin{array}{l}\text { The assessment of dominant } \\
\text { resource components }\end{array}$ & $\begin{array}{l}\text { The structure of indicators forming an innovative } \\
\text { potential }\end{array}$ & $\begin{array}{l}\text { An integrated assessment of } \\
\text { innovative potential }\end{array}$ \\
\hline
\end{tabular}

Source: Own classification

The resource-based approach to evaluating of innovative potential involves analysis of the adequacy of resources determining potential for innovative activities. In many scientific works the financial resource is contemplated as a key one, still the analysis of only financial sources does not allow to evaluate the other types of resources, because only the availability of opportunities for investments does not determine the ability to build up an innovative potential in the region.

The structural approach is the most frequently encountered in the scientific literature, it is based on calculating indicators of structural components of innovative potential and the evaluation of their changes. A set of structural components (technological, manufacturing, personnel, etc.) is segregated and then a set of comparative indicators of their change is assembled. An advantage of this approach is the universality, complexity and the ability to take into account key performance indicators of a specific region.

The productive approach consists in obtaining assessments about an attainment of planned targets as a result of realization of the innovative potential. A special feature of this approach is the orientation toward the achievement of performance indicators for innovation activities in the region and development of innovative potential. One disadvantage of this approach is the difficulty to determine what factors and to what extent have influenced on the use of innovative potential.

In order to evaluate the innovative potential of Hot Dry Rock geothermal technology it is proposed to apply an integrated methodology based on the strategic planning and forecasting the results of innovation activity. A 5-step diagram of determination of the innovative potential is shown in Table 2.

Table 2: Procedures (a 5-step process) for evaluating the innovative potential

\begin{tabular}{l}
$\begin{array}{l}\text { Defining the objective of an innovation strategy (an implementation of the innovative potential through creating high-tech } \\
\text { products and services) }\end{array}$ \\
\hline $\begin{array}{l}\text { Execution of SWOT analysis and evaluation factors and phenomena that affect the implementation innovative potential. } \\
\text { Identifying internal and external factors contributing or inhibiting to the achievement of strategic objectives }\end{array}$ \\
\hline Defining the gears for the implementation of the innovation strategy. \\
\hline $\begin{array}{l}\text { Indicators of assessment the achievement of objectives (payback period of innovation, specific weight of innovation } \\
\text { products in total volume product output) }\end{array}$ \\
\hline Forecasting results of the implementation of the innovation strategy
\end{tabular}

Source: Own results

\section{Assessment of Hot Dry Rock Geothermal Technology: The SWOT Analysis}

The above procedure is considered for evaluating the innovative potential of hot dry rock geothermal technology for Krasnodar region. Table 3 reports the results of the SWOT analysis outlining strengths and weaknesses are specified for hot dry rock geothermal technology, opportunities and threats are defined for the region.

Electricity supply of the Krasnodar region consumers is provided by own sources only for $34 \%$, approximately $66 \%$ of electricity comes from neighboring regions. The bulk of the heat energy production is supplied by boilers. The average level of boilers deterioration is $67 \%$, in the individual municipal entities it reaches $93 \%$. Consequently, electrical and 
thermal energy produced by Hot Dry Rock geothermal technology will be in high demand in the market because of a lower price.

Table 3: SWOT analysis for the application of Hot Dry Rock geothermal technology for Krasnodar region

\begin{tabular}{|c|c|c|}
\hline SWOT- analysis & Opportunities & Threats \\
\hline & $\begin{array}{l}\text { - A high geothermal gradient. } \\
\text { - High population (the 3th place after Moscow } \\
\text { and the Moscow region) and the relatively high } \\
\text { density of the population in the province ( } 70 \\
\text { pers. /sq.km.), that predetermines an increased } \\
\text { concentration of consumer demand. } \\
\text { - The existence of a legislative activity, enabling } \\
\text { the development of the economy in the } \\
\text { province. } \\
\text { - Development of international relationships, } \\
\text { stimulation of an establishment of the foreign } \\
\text { and joint ventures on the Krasnodar territory. } \\
\text { - The ability to attract foreign investors. } \\
\text { - The lack of energy resources and the high } \\
\text { dependence of the region on energy prices. }\end{array}$ & $\begin{array}{l}\text { - The active development in the region of the } \\
\text { other alternative energy sources (solar energy, } \\
\text { MSW, wind power, hydropower); } \\
\text { - Risk of technological and environmental } \\
\text { problems, which is increased by natural factors } \\
\text { (mudflow and seismological danger, possibility } \\
\text { g of flood in spring); } \\
\text { - A small proportion of investments for the } \\
\text { development of non-traditional renewable } \\
\text { energy sources in the total volume of } \\
\text { investments. } \\
\text { - Inadequate innovation infrastructure. } \\
\text { - The lack of modern technologies providing } \\
\text { qualitative characteristics of producible } \\
\text { products and services. }\end{array}$ \\
\hline $\begin{array}{l}\text { Strengths } \\
\text { An uninterrupted electricity supply of } \\
\text { consumers. } \\
\text { Low cost of electricity and heat. } \\
\text { Environmental clean of the } \\
\text { technology. } \\
\text { Long service life of the well (more } \\
\text { than } 30 \text { years); } \\
\text { High efficiency, reliability, self- } \\
\text { sustainment and insularity of the } \\
\text { system. } \\
\end{array}$ & $\begin{array}{l}\text { Activities to be carried out, to take advantage of } \\
\text { the strengths for the realization of the } \\
\text { opportunities: } \\
\text { - Construction of PetroTPS; } \\
\text { - The further increase in the number of } \\
\text { PetroTPS. }\end{array}$ & $\begin{array}{l}\text { f Activities that use the strengths to avoid the } \\
\text { threats: } \\
\text { - Identifying of the benefits of Hot Dry Rock } \\
\text { geothermal energy in comparison with the other } \\
\text { energy sources and attraction of investors. } \\
\text { - The power facility insurance. }\end{array}$ \\
\hline $\begin{array}{l}\text { Weaknesses } \\
\text { The high cost and the duration of the } \\
\text { well drilling; } \\
\text { Little experience of drilling super- } \\
\text { deep drilling wells; } \\
\text { A weak support from the } \\
\text { government. } \\
\text { The lack of modern equipment. }\end{array}$ & $\begin{array}{l}\text { Activities to be carried out, overcoming } \\
\text { weaknesses, using the provided opportunities: } \\
\text { - the use of drilling shells BC-01; } \\
\text { - Alternative energy development in the region. } \\
\text { - Submitting of drafts to the authorities for their } \\
\text { consideration with a justification of draft's } \\
\text { effectiveness. }\end{array}$ & $\begin{array}{l}\text { Activities that minimize the weaknesses to } \\
\text { avoid the threats: } \\
\text { - Improving of the drilling technology in order to } \\
\text { avoid competition from other sources of energy. }\end{array}$ \\
\hline
\end{tabular}

\section{Source: Own results}

Technology part of the project at the initial stage is determined to a large degree by drilling technology. Out of all examined boring tools a drilling rig BC-01 developed by Russian scientists has proved to be the most suitable. The modern drilling rig BC-01 allows to reduce the time of drilling (when speed of work of the rig is $30 \mathrm{~m} / \mathrm{h}$, time needed for drilling of two $10 \mathrm{~km}$ depth wells amounts approximately 1 month). In order to retrench the cost of establishing a hot dry rock geothermal circulation system; to reduce the cost of electricity and heat received at hot dry rock geothermal stations

\section{Conclusions}

Overall, it becomes apparent that geothermal technologies are one of the most promising areas of developing of renewable energy in the world. In particular, they are of ever growing use in Russian Federation. There are technologies of hot dry rock geothermal energy in the composition of geothermal technologies. They represent technologies of energy development, contained in hot rocks that constitute a new promising method of using the renewable sources of energy.

Our results tackle the question of evaluation of hot dry rock geothermal technology innovative potential for the Black Sea basin and surrounding regions. Based on the comprehensive estimation procedure of the region resources, 
their structure and compiling of performance indicators, estimated figures of hot dry rock geothermal technology innovative potential for the Black sea basin-located Krasnodar region are listed.

The results of the study, given in the article, provides an opportunity to regard development of hot dry rock geothermal energy in the Krasnodar Black Sea region as an important factor of the economy modernization, which is associated with the development of innovative industries, a new job places creation, an improvement of social conditions, and an improvement of environment

\section{Acknowledgement}

The reported study was partially supported by the Ministry of Education and Science of the Russian Federation, research project №26.1795.2014/K

\section{References}

Ahmad, A. L., Yasin, N. H., Derek, C. J. C., \& Lim, J. K. (2011). Microalgae as a sustainable energy source for biodiesel production: a review. Renewable and Sustainable Energy Reviews, 15(1), 584-593

Bilgin, M. (2011). Energy security and Russia's gas strategy: The symbiotic relationship between the state and firms. Communist and Post-Communist Studies, 44(2), 119-127

Isaksson, R., Johansson, P., \& Fischer, K. (2010). Detecting supply chain innovation potential for sustainable development. Journal of Business Ethics, 97(3), 425-442

Kirsten, S. (2014). Renewable Energy Sources Act and Trading of Emission Certificates: A national and a supranational tool direct energy turnover to renewable electricity-supply in Germany. Energy Policy, 64, 302-312

Odeku, K. O. (2013). Shifting towards Sustainable Events by Using Alternative Energy and Energy-Efficient Devices. Mediterranean Journal of Social Sciences, 4(14), 835-845

Smith Stegen, K. (2011). Deconstructing the "energy weapon": Russia's threat to Europe as case study. Energy Policy, 39(10), 65056513

Tchereni, B. H. (2013). A Microeconomic Analysis of Energy Choice Behaviour in South Lunzu Township, Malawi. Mediterranean Journal of Social Sciences, 4(6), 569-578

Turcan, A., Bujor T., \& Bahneanu V. (2013). Application the Statistical Methods for Estimating of Innovation Level. Mediterranean Journal of Social Sciences, 4 (9), 271-278

Yeqing, G., \& Hua, L. (2013). Research on China's Total Energy Consumption and Energy Structure. Mediterranean Journal of Social Sciences, 4(9), 381-386 